\title{
Analysis of The Application of Learning Theory of J.B. Bruner in a Counseling Study Counting Operation to Add Whole Numbers
}

\author{
Ejen Jenal Mutaqin', Neni Nadiroti Muslihah², Nizar Alam Hamdani ${ }^{3}$, Sri Dewi \\ Febriani Sasty ${ }^{4}$
}

1,2,4 Institut Pendidikan Indonesia

3Universitas Garut

jenalmutaqin@institutpendidikan.ac.id

Article History

accepted 05/11/2020

approved $10 / 11 / 2020$

published 01/02/2021

\begin{abstract}
This study was a qualitative descriptive study design which aims to find out the analysis results of the implementation of Jerome S. Bruner's learning theory in learning concept of addition count operations of whole numbers in the first grade of elementary school. Jerome S. Bruner's learning theory is one of the learning theories that emphasizes the learning process using mental, namely the individual who learns to experience what he is learning for himself, so that the process can be recorded in his mind by his own way. The stages of Bruner's learning theory are: (1) the enactive stage, (2) the iconic stage, and (3) the symbolic stage. Data collection techniques in this study used student worksheets, observation, interviews and documentation. Based on the results of the study, it can be concluded that the process of applying Jerome $S$. Bruner's learning theory can have a good effect and increase students' understanding and learning ability in learning addition count operations of whole numbers in the first grade of 1 Mekarsari Elementary School.
\end{abstract}

Keywords: Jerome S. Bruner learning theory, operations of counting the addition of counts, elementary school students

\section{Abstrak}

Penelitian ini merupakan penelitian deskriptif kualitatif yang bertujuan untuk mengetahui hasil analisis penerapan teori belajar Jerome S. Bruner dalam pembelajaran konsep operasi hitung penjumlahan bilangan cacah di kelas I Sekolah Dasar. Teori belajar Jerome S. Bruner merupakan salah satu teori belajar yang menekankan pada proses belajar menggunakan mental, yaitu individu yang belajar mengalami sendiri apa yang dipelajarinya agar proses tersebut dapat direkam dalam pikirannya dengan caranya sendiri. Tahapan teori belajar Bruner yaitu: (1) tahap enaktif,; (2) tahap ikonik,; dan (3) tahap simbolik. Teknik pengumpulan data pada penelitian ini menggunakan lembar kerja siswa, observasi, wawancara dan dokumentasi. Berdasarkan hasil penelitian dapat disimpulkan proses penerapan teori belajar Jerome $\mathrm{S}$. Bruner dapat memberikan pengaruh baik dan meningkatkan pemahaman dan kemampuan belajar siswa pada pembelajaran operasi hitung penjumlahan bilangan cacah di kelas I SDN I Mekarsari.

Kata kunci: teori belajar Jerome S. Bruner, operasi hitung penjumlahan bilangan cacah, sekolah dasar.

Social, Humanities, and Education Studies (SHEs): Conference Series https://jurnal.uns.ac.id/shes

p-ISSN 2620-9284

e-ISSN 2620-9292 


\section{PENDAHULUAN}

Penjumlahan merupakan kompetensi operasi hitung bilangan yang mulai diperkenalkan kepada siswa kelas satu semester kedua (Permendikbud 2013). Kompetensi tersebut sebagaimana diamanatkan dalam Standar Isi Sekolah Dasar/Madrasah Ibtidaiyah tentang Standar Kompetensi yaitu "Melakukan penjumlahan dan pengurangan bilangan sampai dua angka" dan Kompetensi Dasar yaitu "Melakukan penjumlahan bilangan yang hasilnya bilangan dua angka" (Depdiknas, 2006). Penjumlahan adalah perihal atau perbuatan menjumlahkan. Jumlah yang artinya bilangan yang terjadi dari beberapa bilangan yang dikumpulkan menjadi satu (Sulistiowati, 2016:11).

Pentingnya siswa kelas 1 SD mempelajari operasi hitung penjumlahan dan pengurangan adalah sebagai modal awal dalam meneruskan jenjang tingkat sekolah yang lebih tinggi. Karena matematika merupakan pelajaran yang bersifat hierarki maka setiap sub bab yang ada akan sangat berkaitan dengan sub bab berikutnya. Untuk itu siswa kelas 1 harus benar-benar mampu menguasai operasi hitung penjumlahan dan pengurangan sebagai dasar awal untuk mempelajari materi matematika selanjutnya (Sulikah, 2014:1).

Kondisi nyata yang terjadi sekarang terkait hasil belajar siswa kelas 1 SD tentang operasi hitung penjumlahan dan pengurangan kurang begitu maksimal. Terbukti dari 31 siswa hanya ada $42 \%$ atau setara dengan 13 orang siswa yang mampu mengerjakan operasi hitung penjumlahan dan pengurangan. Hal ini terlihat saat proses pembelajaran berlangsung anak itu terlihat bosan, cenderung pasif dan tidak semangat dalam belajar. Perbaikan sudah dilakukan tetap saja belum mendapat hasil yang maksimal. Salah satu penyebab masalah yang seperti ini adalah guru belum menggunakan media dan modifikasi pembelajaran yang tepat dan sesuai dengan keadaan siswa sehingga siswa dalam pembelajaran terlihat pasif, gaduh dan kurang motivasi. Kebanyakan proses pembelajaran yang digunakan adalah pembelajaran konvensional yakni ceramah, tanya jawab. (Sumber wawancara Guru kelas 1 SDN 1 Mekarsari).

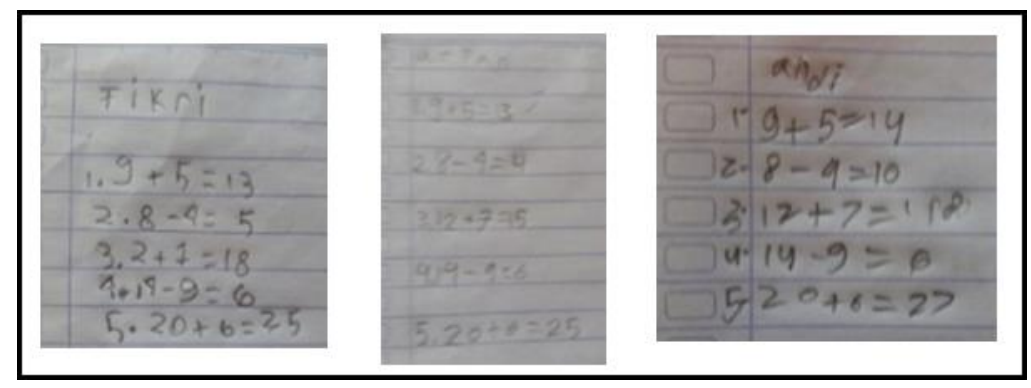

\section{Gambar 1. Contoh Jawaban Siswa}

Berdasarkan hasil observasi awal yang dilakukan peneliti pada siswa kelas I SDN 1 Mekarsari Selaawi, terlihat bahwa siswa kurang memahami dan memaknai operasi hitung penjumlahan bilangan sebuah angka. Kurangnya pemahaman siswa terlihat saat siswa melakukan penjumlahan bilangan satu digit dengan dua digit yang jika ditambahkan antara satuan dengan satuan nilainya akan menjadi puluhan. Misalnya angka $15+7=22$, proses penjumlahannya menggunakan sistem susun ke bawah, dan penulisan angka bilangan harusnya satuan dan satuan sejajar, tetapi anak menuliskan tidak sejajar. Sehingga nanti hasil penjumlahannya ada yang benar ada yang salah, dan menyebabkan anak yang belum mengerti mengalami kesulitan dalam melakukan operasi hitung penjumlahan bilangan cacah.

Kenyataannya di lapangan matematika dirasakan sebagian besar siswa sebagai mata pelajaran yang sulit untuk dipahami dan kurang menyenangkan. Hal ini 
dikarenakan adanya beberapa faktor, diantaranya : (1) masih banyak guru yang belum memperhatikan perkembangan kognitif siswa yang berada pada tahap operasional konkret, (2) kurangnya pemberian penguatan dari guru kepada siswa sesuai tahap perkembangannya, dalam penyampaian materi tentang pemahaman konsep matematika yang masih bersifat abstrak, sehingga proses pembelajaran cenderung monoton, dan (3) kurangnya keterlibatan siswa dalam pembelajaran, dimana siswa lebih bersikap pasif saat proses pembelajaran (Nurngaeni, 2013:2).

Memperhatikan hal tersebut, betapa pentingnya mencari solusi yang memungkinkan untuk mengidentifikasi proses belajar siswa pada materi operasi hitung penjumlahan bilangan cacah. Salah satu solusi yang peneliti gunakan sebagai upaya mengidentifikasi proses belajar siswa pada materi operasi hitung penjumlahan bilangan cacah adalah dengan menerapkan teori Bruner. Bruner (Srinita, 2013:7) mengatakan, "jika seseorang mempelajari suatu pengetahuan, maka pengetahuan itu perlu dipelajari dalam tahap-tahap tertentu.

Adapun tiga tahap dalam teori belajar Bruner (Suwandayani, dkk, 2018:7) yaitu tahap enaktif, tahap ikonik, dan tahap simbolik. Tahap enaktif yaitu suatu tahap pembelajaran sesuatu pengetahuan dimana pengetahuan itu dipelajari secara aktif dengan menggunakan benda-benda konkrit atau menggunakan situasi yang nyata. Tahap ikonik yaitu suatu tahap pembelajaran sesuatu pengetahuan dimana pengetahuan itu dipresentasikan (diwujudkan) dalam bentuk bayangan visual (visual imagery), gambar, atau diagram, yang menggambarkan kegiataan konkrit atau situasi konkrit yang terdapat pada tahap enaktif. Tahap simbolik yaitu suatu tahap pembelajaran dimana pengetahuan itu direpresentasikan dalam bentuk simbol-simbol abstrak (abstract, symbols, yaitu suatu simbol-simbol arbiter yang dipakai berdasarkan kesepakatan orang-orang dalam bidang yang bersangkutan), baik simbol-simbol verbal (misalnya huruf-huruf, kata-kata, kalimat-kalimat), lambang-lambang matematika, maupun lambang-lambang abstrak yang lain.

Tiga tahap dalam proses belajar yang dikemukakan oleh Bruner ini sangat sesuai apabila diterapkan di sekolah dasar karena anak usia SD masih berada dalam tahap berpikir konkret. Teori belajar yang dikemukakan Jerome S. Bruner tersebut diharapkan dapat mengatasi permasalahan yang terjadi di kelas rendah sekolah dasar (SD) khususnya dengan memanfaatkan alat peraga atau media pada saat proses pembelajaran penjumlahan bilangan. Oleh karena itu, maka yang menjadi fokus dalam penelitian ini adalah "Bagaimana analisis proses penerapan teori belajar Bruner dalam pembelajaran konsep operasi hitung penjumlahan bilangan cacah di kelas I Sekolah Dasar?"

\section{METODE}

Penelitian ini adalah penelitian deskriptif kualitatif yang digunakan untuk mengetahui suatu penerapan teori belajar dalam pembelajaran operasi hitung. Prosedur kualitatif tetap mengandalkan data berupa teks dan gambar (Creswell, 2017:24). Instrumen dalam penelitian ini peneliti sendiri sebagai instrumen utama, Lembar Kerja Siswa (LKS), observasi dan wawancara. Partisipan penelitian ini adalah tiga orang siswa kelas I Sekolah Dasar. Adapun langkah-langkah dalam melaksanakan desain pelaksanaan penelitian, yaitu: Perencanaan Penelitian, Pelaksanaan Tindakan, Pengumpulan data, dan Kesimpulan/verifikasi. Tempat penelitian dilaksanakan di Rumah, berdasarkan pertimbangan sebagai berikut adanya peraturan pemerintah mengenai kegiatan belajar di rumah secara online dan social distancing pada masa Pandemi Covid-19, sehingga penelitian tidak bisa dilaksanakan di sekolah, tempat umum dan partisipannya terbatas. Teknik pengumpulan data penelitian ini dilakukan dalam upaya mengumpulkan data dan informasi yang dibutuhkan. Teknik pengumpulan data menggunakan pada penelitian ini adalah menggunakan observasi, wawancara, dan dokumentasi. 
HASIL DAN PEMBAHASAN

Teori belajar Bruner menekankan pembelajaran pada tahap perkembangan kognitif partisipan, yaitu tahap enaktif, tahap ikonik, dan tahap simbolik, sehingga partisipan dapat memahami konsep dengan baik. Deskripsi untuk melihat sejauh mana keberhasilan penerapan teori belajar Bruner dalam operasi penjumlahan bilangan cacah, peneliti menjabarkan pembahasan data hasil penelitian tersebut menjadi 3 poin, yaitu pada alternatif pembelajaran 1, alternatif pembelajaran 2, dan pembelajaran alternatif 3.

1. Alternatif Pembelajaran 1

Berdasarkan hasil pengolahan dan analisis data terdapat temuan bahwa proses penerapan teori belajar Bruner disertai dengan menggunakan media konkret untuk mempermudah partisipan memahami materi yang diajarkan. Media yang digunakan dalam pembelajaran alternatif 1 yaitu stick ice cream dan keranjang hitungan, akan tetapi karena semua partisipan merupakan anak laki-laki, daya tarik partisipan terhadap pembelajaran cenderung tidak begitu antusias. Hal ini sependapat dengan yang dikemukan oleh Hamalik (Arsyad, 2013:19) bahwa pemakaian media pengajaran dalam proses belajar mengajar dapat membangkitkan keinginan dan minat yang baru, membangkitkan motivasi dan rangsangan kegiatan belajar, dan bahkan membawa pengaruh-pengaruh psikologis terhadap siswa. Oleh karena itu, pemilihan alat peraga yang sesuai dengan psikologis siswa juga sangat penting dilakukan.

Penggunaan media yang kurang menarik dapat memengaruhi perhatian dan kefokusan partisipan ketika melaksanakan kegiatan pembelajaran. Perhatian banyak dipengaruhi oleh berbagai faktor, baik faktor pada rangsangan maupun faktor individu. Faktor-faktor yang mempengaruhi perhatian dari aspek individu antara lain: (1) minat; (2) kondisi fisik atau kesehatan; (3) keletihan; (4) motivasi; (5) kebutuhan perhatian; (6) harapan; dan (7) karakteristik kepribadian (Surya, 2015:40-41).

Salah satu partisipan ada yang motivasi belajarnya masih kurang, sehingga ia tergesagera dalam mengerjakan LKS karena ingin segera bermain dari pada belajar, dan berpengaruh terhadap hasil dari proses pembelajarannya yang tidak optimal. Ali Imron (Siregar dan Hartini, 2010:55) mengemukakan 4 upaya yang dapat dilakukan oleh guru guna meningkatkan motivasi belajar pembelajaran yaitu: (1) mengoptimalkan penerapan prinsip-prinsip pembelajaran; (2) Mengoptimalkan unsur-unsur dinamis pembelajaran; (3) Mengoptimalkan pemanfaatan upaya guru dalam membelajarkan pembelajaran juga menjadi faktor yang mempengaruhi motivasi; dan (4) Mengembangkan aspirasi dalam belajar.

\section{Alternatif Pembelajaran 2}

Selanjutnya dalam alternatif pembelajaran 2, mengenai operasi hitung penjumlahan satu digit dengan satu digit yang hasilnya dua digit pada bilangan 20. Dengan menggunakan alat peraga lego, ini menunjukkan antusias partisipan dalam belajar, karena partisipan pada usia 7-11 tahun ini masih sangat menyukai pembelajaran dengan menggunakan media konkret. (Danim, 2014:64) Perkembangan kognitif pada siswa usia antara 7-11 tahun menurut Piaget disebut tahap operasi konkret (concrete operations stage). Anak usia ini dibatasi untuk berpikir konkret-nyata, pasti, tepat, dan uni-direksional, istilah yang lebih menunjukan pengalaman nyata dan konkret ketimbang abstraksi.

Penggunaan media pengajaran yang tepat dalam proses belajar-mengajar sangat penting dilakukan oleh guru demi menunjang penggunaan metode mengajar yang dipergunakan guru. Penggunaan media pengajaran dapat mempertinggi proses dan hasil pengajaran adalah berkenaan dengan taraf berpikir siswa. Taraf berpikir manusia mengikuti tahap perkembangan dimulai dari berpikir konkret menuju ke berpikir abstrak, di mulai dari berpikir sederhana menuju ke berpikir kompleks (Sudjana \& Ahmad, 2011:3). 
Di tahap ikonik siswa mengalami kesulitan ketika diminta untuk menggambarkan pola bentuk lego yang mereka susun. Ada salah satu partisipan yang sangat tidak menyukai pembelajaran menggambar, sehingga hasil gambarnya sangat tidak beraturan dan bentuknya abstrak. Pola perkembangan seni rupa pada masa kanak-kanak merupakan periode berkembangnya kreativitas dan karakteristik mental anak sebagaimana dikemukakan Duquet (Nurfatoni, Dkk, 2013:2) bahwa: "...a child who does not draw is an anomaly, and particularly so in the years between 6 and 10, which outstandingly the golden age of creative expression". Pada rentang usia enam sampai sepuluh tahun merupakan masa keemasan dari ekspresi kreatif, bahkan daya kreatif dan fantasi yang kuat dihasilkan pada jenjang kelas 1 sampai kelas 3 Sekolah Dasar.

Kesukaan partisipan terhadap pembelajaran menggambar itu tergantung minat dan bakat siswa, (Mahmudah, 2017:31) minat adalah kecenderungan yang tetap untuk memperhatikan, mengenang dan diikuti dengan perasaan senang sehingga diperoleh sebuah kepuasan. Minat pengaruhnya besar terhadap belajar, karena jika bahan pelajaran yang dipelajari tidak sesuai dengan minat siswa dan tidak ada daya tariknya, maka siswa tidak akan belajar bersungguh-sungguh. Sedangkan bakat atau aptitude adalah kemampuan untuk belajar, kemampuan baru terealisasi menjadi kecakapan yang nyata sesudah belajar dan berlatih.

Pada tahap simbolik partisipan ada yang mengalami kesulitan dalam menuliskan beberapa simbol angka, ada yang terbalik karena lupa bentuk angkanya, ada yang bentuknya menyerupai simbol lain, ada yang posisi angkanya miring, dan beraneka ragam keunikan dari partisipan. Kesulitan belajar adalah masalah yang dialami siswa dan menghambat usaha dalam mencapai tujuan belajar. Pada tingkat tertentu anak didik dapat mengatasi kesulitan belajarnya, tanpa harus melibatkan orang lain. Pada kasus-kasus tertentu, karena anak didik belum mampu mengatasi kesulitan belajarnya, maka bantuan guru, dan orang lain sangat diperlukan (Angranti, 2016:4).

Dengan bimbingan guru dan proses latihan menulis simbol-simbol angka, akan membuat partisipan menjadi telaten dalam menuliskan simbol angka dengan baik dan benar. Jaworsi (Wulansari, 2014:3) mengatakan bahwa dalam mengelola pembelajaran tidaklah mudah karena kadang-kadang dijumpai para siswa mengalami kesulitan dalam belajarnya. Oleh karena itu, dalam mengajarkan sebuah materi pelajaran di sekolah, hendaknya dikaitkan dengan taraf berpikir anak.

\section{Alternatif Pembelajaran 3}

Kemudian dalam alternatif pembelajaran 3 mengenai operasi hitung penjumlahan satu digit dengan dua digit yang hasilnya dua digit sampai bilangan 20 ini, dapat diaplikasikan terhadap siswa kelas I Sekolah Dasar dengan baik dan berhasil. Dengan menggunakan media kelereng, ini sangat mempengaruhi antusias partisipan dalam belajar, karena partisipan pada usia 7-11 tahun ini masih sangat menyukai pembelajaran dengan menggunakan media konkret. Menurut Piaget (Heruman, 2012:1) kemampuan yang tampak pada fase operasional konkret adalah kemampuan dalam proses berpikir untuk mengoperasikan kaidah-kaidah logika, meskipun masih terikat dengan objek yang bersifat konkret. Usia perkembangan kognitif siswa SD masih terikat dengan objek konkret yang dapat ditangkap oleh panca indera. Dalam pembelajaran matematika yang abstrak, siswa memerlukan alat bantu berupa media, dan alat peraga yang dapat memperjelas apa yang akan disampaikan oleh guru sehingga lebih cepat dipahami dan dimengerti oleh siswa (Sa'diyah, 2017:35)

\section{SIMPULAN}

Berdasarkan hasil penelitian dan pembahasan pada bab sebelumnya, dapat disimpulkan bahwa proses penerapan teori belajar Bruner dalam pembelajaran konsep operasi hitung penjumlahan bilangan cacah di kelas I Sekolah Dasar dapat disimpulkan bahwa proses analisis penerapan teori belajar Jerome S. Bruner ini sangat 
baik digunakan bahkan dapat meningkatkan pemahaman siswa dalam pembelajaran konsep operasi hitung penjumlahan bilangan cacah di kelas I SD. Kemampuan siswa pada pembelajaran operasi hitung pengurangan dengan mengimplementasikan teori belajar Jerome S. Bruner ini hasilnya baik, siswa dapat mengaplikasikan pembelajaran yang diperoleh ke dalam kehidupannya sehari-hari, dan menjadikan siswa lebih mandiri dan kreatif dalam menghadapi permasalahan dalam pembelajaran matematika. Analisis penerapan teori belajar Jerome S. Bruner dengan menggunakan tiga tahapan, yaitu: 1) enaktif; 2) ikonik; dan 3) simbolik, ini dapat mengetahui perkembangan siswa secara bertahap mulai dari yang sederhana ke yang rumit, dari yang mudah ke yang sulit dan dari yang nyata atau konkret ke yang abstrak. Penggunaan alat peraga pada stick ice cream, lego dan kelereng sangat baik dan tepat digunakan oleh anak kelas 1 Sekolah Dasar sesuai dengan tahap perkembangan siswa pada usianya.

\section{DAFTAR PUSTAKA}

Abi Krida, Prasetya. (2012). Proses Pembelajaran Musik bagi Kelompok Band Just 4_U di SMA BPOKRI 1 Yogyakarta. S1 thesis. Universitas Negeri Yogyakarta: Tidak diterbitkan.

Angranti, Wiwik. (2016). Problematika Kesulitan Belajar Siswa. Jurnal Gerbang Etam. 10(1):28-37.

Arsyad, Azhar. (2013). Media Pembelajaran. Edisi Revisi Jakarta: PT Rajagrafindo Persada.

Creswell, J.W., (2017). Research Designe Pendekatan Metode Kualitatif, Kuantitatif, dan Campuran. Yogyakarta: Pustaka Pelajar.

Danim, Sudarwan. (2017). Perkembangan Peserta Didik. Bandung: Alfabeta.

Depdiknas. (2006). Kurikulum Tingkat Satuan Pendidikan (KTSP) untuk Sekolah Dasar/ MI. Jakarta: Depdiknas.

Heruman. (2014). Model Pembelajaran Matematika Di Sekolah Dasar. Bandung: PT Remaja Rosdakarya.

Mahmudah, Nurul. (2017). Pengembangan Buku Panduan Menggambar dan Mewarnai Ragam Hias dengan Teknik Gradasi pada Siswa Kelas V SDN Kajar 01 Pati. (Skiripsi). Jurusan PGSD Universitas Negeri Semarang: Tidak diterbitkan

Nurfatoni, Septian, Dkk. (2013). Kajian Gambar Ekspresi Karya Siswa Tingkat Sekolah Dasar. Jurnal Edukasi. 1(3):1-15.

Nurngaeni, Siti. (2013). Penerapan Teori Bruner Untuk Meningkatkan Pemahaman Konsep Pembagian Bilangan Asli Siswa Kelas II SDN 3 Bajong Bukateja Purbalingga. (Skiripsi). Jurusan PGSD Universitas Negeri Yogyakarta: Tidak diterbitkan.

Permendikbud Republik Indonesia Nomor 69. (2013). Tentang Kerangka Dasar dan Struktur Kurikulum Sekolah Dasar/Madrasah Ibtidahiyah.

Sa'diyah, Rika. (2017). Pentingnya Melatih Kemandirian Anak, Jurnal Koordinat. $\mathrm{XVI}(1): 31-46$.

Siregar, Eveline \& Hartini Nara. (2011). Teori Belajar dan Pembelajaran. Bogor: Penerbit Ghalia Indonesia.

Srinita, Yosi. (2013). Teori Belajar Menurut Bruner. Makalah Pendidikan Matematika Online. Universitas Riau.

Sudjana, N. \& Ahmad R. (2011). Media Pengajaran. Bandung: Sinar Baru Algensindo. Sugiyono. (2013). Metode Penelitian Pendidikan. Bandung: Alfabeta.

Sulikah, Sulikah. (2014). Peningkatan Kemampuan Mengerjakan Operasi hitung Penjumlahan dan Pengurangan Menggunakan Metode Demonstrasi dan Media Potongan Lidi pada Siswa Kelas 1 Semester 2 SDN Sedayu Tahun 2013/2014. Skripsi thesis, Universitas Muhammadiyah Surakarta. 
Sulistiowati, Heri. (2016). Peningkatan Hasil Belajar Matematika Materi Penjumlahan Dan Pengurangan Bilangan Melalui Metode Jarimatika Pada Siswa Kelas II MI Tamrinul Ulum Jetis Gentan Susukan Kab. Semarang Tahun Pelajaran 20162017. (Skripsi). Jurusan PGMI IAIN Salatiga: Tidak diterbitkan.

Surya, Mohamad. (2015). Psikologi Guru Konsep dan Aplikasi dari Guru, untuk Guru. Bandung: Alfabeta.

Suwandayani, dkk. (2018). Pembelajaran Matematika yang Menyenangkan. Malang: Universitas Muhammadiyah Malang. Suyono dan Hariyanto. (2017). Belajar dan Pembelajaran. Bandung: PT Remaja Rosdakarya.

Wulansari, Rianti. (2014). Meningkatkan Hasil Belajar

Operasi Hitung Bilangan Pecahan Melalui Implementasi Teori Belajar Bruner Pada Siswa Kelas IV SDN Wiro Kabupaten Klaten. (Skripsi). Jurusan PGSD Universitas Negeri Yogyakarta: Tidak diterbitkan. 